\title{
Aulacostephanid ammonites from the Kimmeridgian (Upper Jurassic) of British Columbia (western Canada) and their significance for correlation and palaeobiogeography
}

\author{
MikHAIL A. ROgOV \& TERRY P. POULTON
}

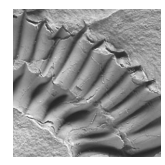

\begin{abstract}
We present the first description of aulacostephanid (Perisphinctoidea) ammonites from the Kimmeridgian of Canada, and the first illustration of these ammonites in the Americas. These ammonites include Rasenia ex gr. cymodoce, Zenostephanus (Xenostephanoides) thurrelli, and Zonovia sp. A from British Columbia (western Canada). They belong to genera that are widely distributed in the subboreal Eurasian Arctic and Northwest Europe, and they also occur even in those Boreal regions dominated by cardioceratids. They are important markers for a narrow stratigraphic interval in the Cymodoce Zone (top of Lower Kimmeridgian) and the lower part of the Mutabilis Zone (base of Upper Kimmeridgian) of the Northwest European standard succession. In Spitsbergen and Franz Josef Land, the only Upper Kimmeridgian aulacostephanid-bearing level is the Zenostephanus (Zenostephanus) sachsi biohorizon, which very likely belongs to the Mutabilis Zone. Expansion of Zenostephanus from Eurasia, where it is present over a large area, into British Columbia, is approximately correlative with a transgressive event that also led to expansion of the Submediterranean ammonite genus Crussoliceras through the Submediterranean and Subboreal areas slightly before Zenostephanus. - Key words: Kimmeridgian, aulacostephanids, Zenostephanus, Rasenia, British Columbia, palaeobiogeography, sea-level changes.

RogOV, M.A. \& PoulTON, T.P. 2015. Aulacostephanid ammonites from the Kimmeridgian (Upper Jurassic) of British Columbia (western Canada) and their significance for correlation and palaeobiogeography. Bulletin of Geosciences 90(1), 7-20 (5 figures). Czech Geological Survey, Prague. ISSN 1214-1119. Manuscript received January 31, 2014; accepted in revised form October 2, 2014; published online November 25, 2014; issued January 26, 2015.
\end{abstract}

Mikhail A. Rogov (corresponding author), Geological Institute of RAS, Pyzhevski lane 7, 119017 Moscow, Russia; russianjurassic@gmail.com •Terry P. Poulton, Geological Survey of Canada, 3303-33 Street NW, Calgary, AB T2L 2A7; Terry.Poulton@nrcan.gc.ca

We provide here the first description and illustration of aulacostephanid ammonites from British Columbia, western Canada. Aulacostephanid ammonites are the main components of the guide-assemblages of the zonal and infrazonal subdivision of the Subboreal Upper Oxfordian and Kimmeridgian of northwestern Eurasia, and all index species of the standard Kimmeridgian zonal succession belong to this family. Outside the Subboreal areas, these ammonites are relatively uncommon, and they are especially scarce in Submediterranean sections. They usually occur only at certain stratigraphic levels in the Arctic, where Boreal cardioceratids dominated the Kimmeridgian ammonite successions of the Barents Sea shelf, Svalbard and Franz Josef Land.

A few aulacostephanid ammonites have been reported previously (as Rasenia, Aulacostephanus, Rasenioides and Pararasenia) from Arctic Canada (H. Frebold in Tan \& Hills 1978, p. 63, fig. 12.5; Harrison et al. 2000, p. 431) and British Columbia (T. Poulton in Evenchick et al. 2001, 2010; Evenchick \& Thorkelson 2005), but were neither figured nor described. Those from British Columbia have been re-examined, and form the basis of this report. However, the last two of those reported genera are now considered to be misidentifications, and Aulacostephanus has now been subdivided and partially replaced with new genera (Callomon et al. 2009), including Zenostephanus.

The fossils were collected in the northern part of the Bowser sedimentary basin in northwestern British Columbia (Fig. 1), and were submitted for identification during the course of geological mapping projects. The ammonites described here document a level that is generally poorly represented by ammonites in western Canada, largely as a result of overwhelming clastic sedimentation rates in the tectonically active post-Oxfordian Jurassic. Fossils have been critical for geological mapping, and for our understanding of the stratigraphy and tectonics of this part of the Canadian western Cordillera, because the lithofacies 
units are time-transgressive, repetitive in their stratigraphy, tectonically deformed and dislocated (Evenchick et al. 2010), and not continuously exposed.

Those few Kimmeridgian ammonites that are available for study are generally isolated fragments submitted for study by mapping geologists, without biostratigraphic context, sequence, nor immediate associations of fossils. They were generally not found in contexts that were amenable to the description of stratigraphic sequences.

\section{Geological and palaeogeographic setting}

The ammonites were found in strata of the Bowser Lake Group (Middle Jurassic to Lower Cretaceous) in the northern part of the Bowser Basin (Evenchick et al. 2010). This basin developed on top of the Early and Middle Jurassic Hazelton volcanic arc complex on Stikinia or Stikine exotic terrane, a result of loading below an obducted Cache Creek oceanic complex, thermal subsidence as Stikinia volcanism decreased (e.g. Gagnon et al. 2009), or transtension in a strike-slip regime. Stikinia was one of many oceanic or peri-continental terranes within the palaeo-Pacific (Panthalassa) Ocean (Marsden \& Thorkelson 1992, Gagnon et al. 2012) that were accreted to western North America (Pangaea or early Laurasia) during the Mesozoic.

The clastic sediments in the basin came from multiple sources, including contemporaneous volcanic centers (Evenchick et al. 2010). In its currently preserved form (the basin has been laterally compressed, rotated, and transported probably northward along the western continental margin), an offlapping series of wedges which become finer-grained and vary to deeper water facies to the south and west, has been recognized in the northern portion of the Bowser Basin (Evenchick et al. 2010). Relatively deep marine, condensed and fine-grained sedimentary rocks of Middle Jurassic age vary upward within the Bowser Lake Group, to nonmarine, coal-bearing strata in the Early Cretaceous.

The original location and orientation of the western Cordilleran terranes have not been well resolved as yet, nor have the timing of the many amalgamation and accretionary events that are evident. The Jurassic strata have been involved in Cretaceous and Tertiary tectonic displacements and rotations, eroded, buried below a thick younger sequence, and metamorphosed in certain western areas. Field geological observations and relationships, palaeomagnetic studies, and palaeobiogeography deduced from the fossils, have led to conflicting tectonic interpretations (e.g. Haggart et al. 2006).

In particular, the palaeolatitude of the Bowser Basin during the Kimmeridgian, and its relative proximity to western North America within the northeastern palaeo-Pacific at that time, are contentious, and it is beyond the scope of this report to speculate on the original palaeogeographic disposition of Bowser Basin. Comprehensive syntheses have been produced (e.g. Nokleberg et al. 2001, Evenchick et al. 2007), but discussions of conflicting interpretations are readily available (e.g. Haggart et al. 2006). Palaeogeographic conclusions from the affinities of the primarily Boreal Late Jurassic faunas of the basin (e.g. Taylor et al. 1984, Poulton et al. 1993, this report) are not definitive, but have been suggested to indicate little displacement with respect to the continent at about the Jurassic-Cretaceous boundary (Jeletzky 1984). This conforms to the similarity of Early Bajocian and Bathonian faunas of Stikinia and Bowser Basin (Tipper \& Richards 1976, Hall et al. 1991, Poulton et al. 1993) with those of cratonic southwestern Canada (Athabascan part of East Pacific Realm; Taylor et al. 1984).

The abundance of phylloceratids in the Upper Callovian and Lower Oxfordian strata of Bowser Basin (e.g. Evenchick et al. 2010) indicates ready access to open waters of the Panthalassa/proto-Pacific ocean to the west, according to Callomon (in Poulton et al. 1994), which might support those interpretations that westernmost oceanic arcs of the Insular Belt (Fig. 1) were not accreted until the Cretaceous. Bowser Basin is only one of a number of Late Jurassic to Early Cretaceous basins along the western continental margin (McLelland et al. 1992), some of them clearly connected to volcanic arcs to their west (Nokleberg et al. 2001) but their mutual relationships are not yet clear.

The strata in Bowser Basin were deformed in a Cretaceous compressional tectonic event (Skeena Orogeny of Evenchick 1991), and many of the fossils come from different fault blocks or slices, whose mutual relationships have been deduced to a significant extent from the fossils contained in them.

\section{Fossil localities and curation}

The fossils illustrated in this report are curated in the Type Collection of the Geological Survey of Canada (GSC), 601 Booth Street, Ottawa, Canada. All other fossils mentioned are stored in the research collections of the GSC.

GSC Locality 28982. - Collected by R. Baragar for J.A. Roddick in 1956, 1 mile $(1.6 \mathrm{~km})$ north of head of Owlet Creek (west fork), northwestern Bowser Lake map area (NTS 104A/13; UTM 446680/6304493). Previously reported by Evenchick et al. (2001, p. 35, as O-28982). The collection contains Z. (Z.) cf. ranbyensis (Arkell \& Callomon), identified by J. Jeletzky (in Evenchick et al. 2001) as "ammonite (possibly Rasenia sp.)", and Buchia concentrica (J. Sowerby). This locality is on a ridge, in the middle portion of what might be a stratigraphic succession (neither 

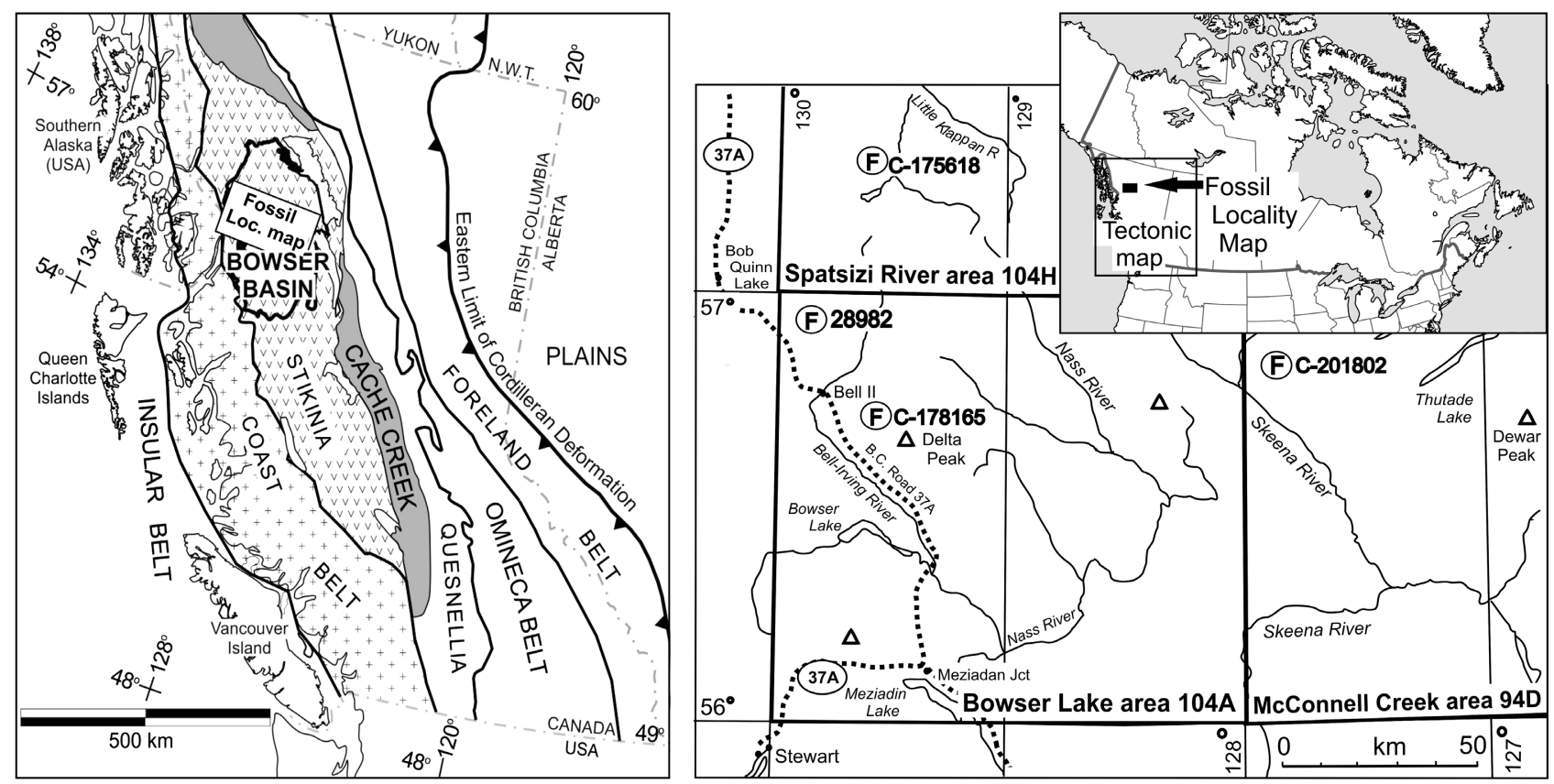

Figure 1. Regional tectonic and fossil locality maps, showing location of Bowser sedimentary basin on Stikinia exotic terrane, now preserved in northwestern British Columbia, western Canadian Cordillera, and the fossil localities described in this report. The fossil locality map shows the outlines of map areas in the national topographic map system: Bowser Lake map area (104A), and parts of McConnell Creek (94D) and Spatsizi River (104H) map areas.

described nor likely suitable for description) that has produced, from south-to-north over approximately $8 \mathrm{~km}$, isolated collections including Cardioceras sp., Buchia concentrica (J. Sowerby), Buchia concentrica (J. Sowerby) / mosquensis (Buch), and Buchia sp. aff. fischeriana (d'Orbigny) (i.e. Oxfordian through Tithonian).

GSC Locality C-175618. - Collected by C. Evenchick in 1989, $8 \mathrm{~km}$ west-southwest of the junction of Maitland Creek and Klappan River, southwestern Spatsizi River map area (NTS 104H/5; UTM 6354700/ 464070). Previously reported by Evenchick et al. (2001, pp. 41, 74) and Evenchick \& Thorkelson (2005, p. 205). This collection contains Zenostephanus (Xenostephanoides) thurrelli (Arkell \& Callomon) and Rasenia ex gr. cymodoce (d'Orbigny) (both reported as Aulacostephanus), as well as Adabofoloceras sp., Buchia concentrica (J. Sowerby), many specimens of Mclearnia sp., other undeterminable bivalves, and possible scaphopods. There are apparently no other fossil localities in the vicinity.

GSC Locality C-178165. - Collected for C. Evenchick in 1991. About $1 \mathrm{~km}$ northeast of Mt. Skowill, and northwest of Delta Peak, in northwestern Bowser Lake map area (NTS 104A12; UTM 461260 6284800). Previously reported in Evenchick et al. (2001, p. 40) and Gagnon et al. [2012, Suppl. Data, p. 3 (OW3)]. Evenchick et al. (2010, p. 244) noted that the collection comes from turbidites about $120 \mathrm{~m}$ above the contact with Middle Jurassic rocks of the Hazelton Group, and that it contains probable contemporaneous volcanogenic zircons dated as $152.4 \mathrm{Ma}$. It lies on the north side of "Oweegee Dome", a pre-Late Jurassic uplift that exposes Palaeozoic rocks in its core below a relatively thin Jurassic sequence (Greig 1992, Greig et al. 1993, Evenchick \& Thorkelson 2005). Besides Zenostephanus (Xenostephanoides) thurrelli (Arkell \& Callomon) (reported previously as Aulacostephanus), it also includes Adabofoloceras sp., Phylloceras sp., Buchia concentrica (J. Sowerby), and other bivalves. Other fossil localities in the vicinity of this locality contain Early or Middle Oxfordian Cardioceras sp., and the succession here continues in shallow marine facies into the Early Cretaceous (Evenchick \& Thorkelson 2005).

GSC Locality C-201802. - Collected for C. Evenchick in 1992 . Mt. Geodfrey, east ridge, about $1 \mathrm{~km}$, in northwestern McConnell Creek map area (NTS 94D13; UTM 566775 6298600; NAD 83). Previously reported as Early Kimmeridgian in Evenchick et al. (2001, pp. 55, 74). This collection contains Zenostephanus (Xenostephanoides) thurrelli (Arkell \& Callomon), Zonovia sp. A and Rasenia ex gr. cymodoce (d'Orbigny), and unidentified bivalves. Another collection from the same locality (C-201800, in Evenchick et al. 2001, p. 55) contains Buchia concentrica etheringtoni (Meek), Arctotis (?) sp., and other bivalves. 


\section{Systematic palaeontology}

Suborder Stephanocerina Besnosov, 1960

Superfamily Perisphinctoidea Steinmann, 1890

Family Aulacostephanidae Spath, 1924

\section{Genus Zenostephanus Callomon, Donovan \& Van den Hoek Ostende, 2009}

\section{Subgenus Xenostephanoides $[\mathrm{m}]^{1}$ Arkell \& Callomon, 1963}

\section{Zenostephanus (Xenostephanoides) thurrelli (Arkell \& Callomon, 1963)}

Figure 2A1-3, B1-3, C

1930 Rasenia sp. indet. cf. groenlandica (Ravn). - Frebold, pl. XXII, fig. 2.

1962 Aulacostephanus (Xenostephanus) sp.; Ziegler, pl. 22, fig. 11, 12.

1963 Aulacostephanus (Xenostephanoides) thurrelli sp. nov.; Arkell \& Callomon, p. 230, pl. 30, figs 1-3.

1969 Zonovia thurrelli (Arkell \& Callomon). - Mesezhnikov, p. 122, pl. XVI, fig. 2.

1983 Zonovia cf. ranbyensis (Arkell \& Callomon). - Erschova, pl. XV, fig. 3.

1984 Zonovia (Xenostephanoides) thurrelli (Arkell \& Callomon). - Mesezhnikov, p. 120, pl. XXVII, fig. 3; pl. XXVIII, fig. 2 [non pl. XXIV, fig. 2].

2001 Aulacostephanus sp.; Evenchick et al., pp. 40, 41.

2001 Aulacostephanus (?) sp.; Evenchick et al., pp. 55, 74 (part).

2005 Aulacostephanus sp.; Evenchick \& Thorkelson, p. 205.

2007 Zonovia (Xenostephanus) sachsi Mesezhnikov. Repin et al., pl. XIV, fig. 5 only.

2010 Aulacostephanus (Xenostephanus) aff. staintonensis (Arkell \& Callomon). - Evenchick et al., p. 239.

2012 Aulacostephanus sp.; Gagnon et al., Suppl Data, p. 3 (OW3).

Material. - Three specimens from three localities: GSC figured specimen 134795 from GSC Locality C-178165
(Bowser Lake map area, 104A, Fig. 1) GSC figured specimen 134799 from GSC Locality C-201802 (McConnell Creek map area, 94D) and GSC figured specimen 134822 from GSC Locality C-175618 (Spatsizi River map area, 104H).

Description. - This species is represented by three specimens, one about half complete (Fig. 2B1-B3), another preserving only a partial, small whorl fragment (Fig. 2A1-A3) and a third preserved as a partial imprint (Fig. 2C). All characteristic features of $Z$. (X.) thurrelli, such as evolute coiling, small size and mainly biplicate, moderately spaced ribs, are clearly visible. Such ribbing appears very early in ontogeny, and can be determined at a diameter of about $0.5 \mathrm{~cm}$. On the earliest whorls visible, the primaries split slightly below the middle of the whorl into two rectiradiate secondaries. Beyond a diameter of about $1-1.5 \mathrm{~cm}$, the primaries form elongated nodes close to the umbilical margin, and beyond a diameter of about $3 \mathrm{~cm}$, they are welldeveloped, conspicuous elongated umbilical nodes separated from the secondaries by a narrow, depressed lateral band or groove. This groove is crossed by only a few simple ribs, and by the much-weakened umbilical ends of the secondary ribs. The cross-section at the maximum diameter observed is subquadrate to trapezoidal, widest at the umbilical nodes. The flanks are gently rounded towards the ventrolateral edges of the shell, where the secondary ribs terminate abruptly in a slight swelling. The venter consists of a narrow, smoothly floored groove between the weak swellings that terminate the ventral ends of the ribs on either side of it. Triplicate ribs or intercalatories are uncommon even in the inner whorls. Suture line is not visible.

Comparison. - Our specimens most closely resemble the paratype of $Z$. (X.) thurrelli, figured by Arkell \& Callomon (1963, pl. 30, fig. 2). From other Zenostephanus (Xenostephanoides) species, they differ by their relatively widely spaced, mainly biplicate ribs. The ammonites referred to as Z. thurrelli by Malinowska (1986), are considered to be Prorasenia, close to Rasenia evoluta [m] in Birkelund \& Callomon, 1985, and differ from this species by their narrow umbilicus and dense ribbing. One specimen from

Figure 2. Kimmeridgian aulacostephanids from British Columbia. All specimens are figured actual size except Fig. A1-A3 $(\times 2)$. A-C - Zenostephanus (Xenostephanoides) thurrelli Arkell \& Callomon, Mutabilis Zone, Mutabilis Subzone. • A1-A3 - lateral, ventral and cross-section views of GSC figured specimen 134799 from GSC Locality C-201802. • B1-B3 - lateral, ventral and cross-section views of GSC figured specimen 134795 from GSC Locality C-178165. • C - imprint of flattened partial flank, GSC figured specimen 134822 from GSC Locality C-175618. • D - Zenostephanus (Zenostephanus) sp. cf. ranbyensis (Arkell \& Callomon). Imprints of small fragments of flank of an inner whorl, and venter of body chamber. E1, E2 Zonovia(?) sp. GSC figured specimen 134804 from GSC Locality C-201802, same locality as A1-A3. • F, G - Rasenia ex gr. cymodoce (d'Orbigny), Cymodoce Zone. • F1-F3 - lateral, ventral, and cross-section views of GSC figured specimen 134818 from GSC Locality C-201802 (same locality as A1-A3 and E1, E2). • G - cross-section view of GSC figured specimen 134821 from GSC Locality C-175618 (same specimen as Fig. 3A1, A2).

\footnotetext{
${ }^{1}$ Herein and throughout in the text $[\mathrm{m}]-$ microconchs, $[\mathrm{M}]-$ macroconchs
} 


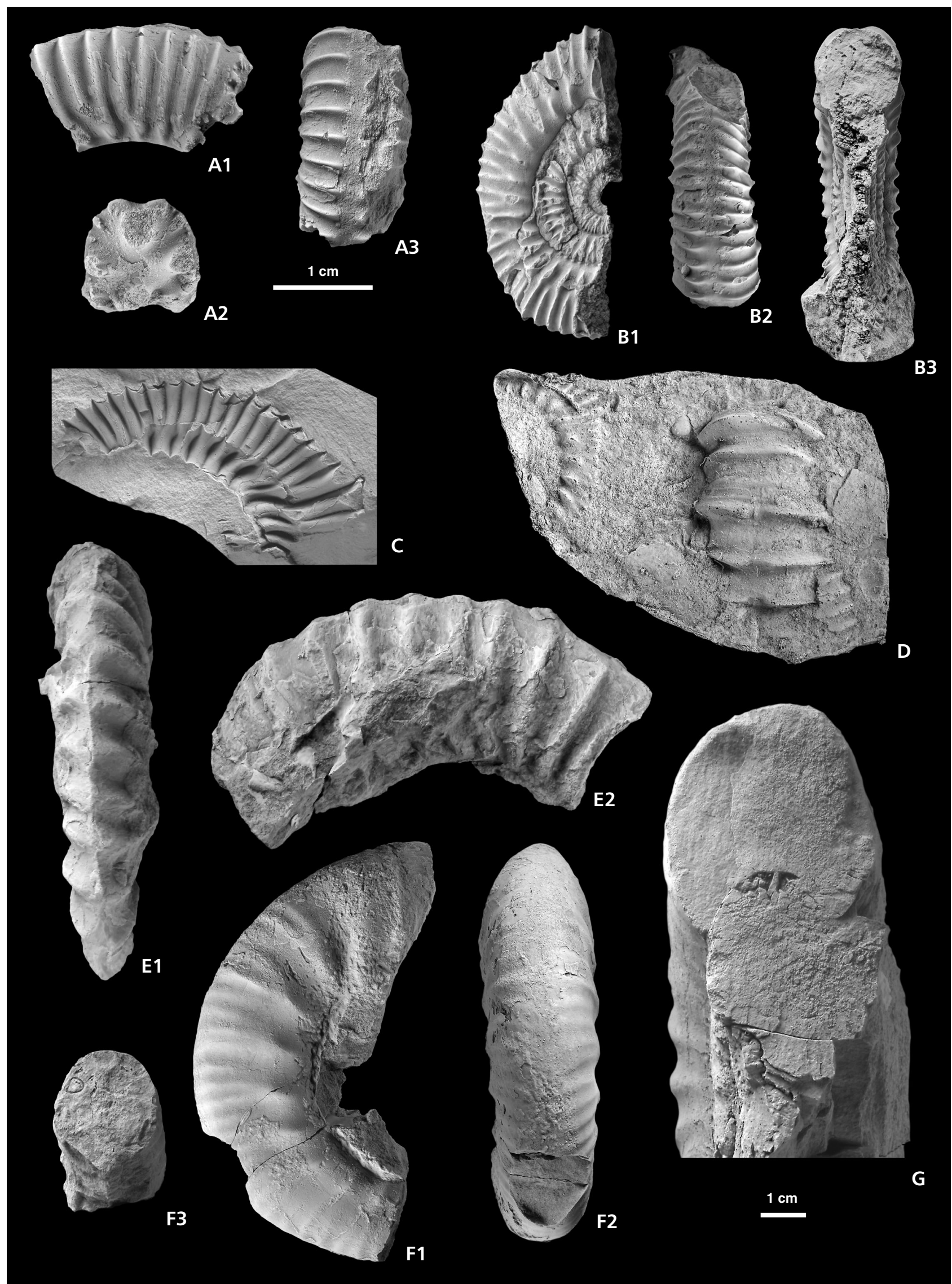


another locality (Fig. 2D), represented by an imprint of a small part of an inner whorl with a high rib ratio, and a partial ventral imprint of the body chamber showing the well-recognized rib interruption, differs from the described species by its higher rib ratio. This ammonite is determined as Z. (Z.) cf. ranbyensis (Arkell \& Callomon), as it shows primaries and secondaries subdivided by a smooth band in the inner whorls and distant ribbing at the body chamber, the typical features of $Z$. (Z.) ranbyensis. It is also close to $Z$. (Z.) ranbyensis, described from the Mutabilis Zone s.s. of Khatanga Depression (Mesezhnikov 1969, p. 121, pl. XVI, fig. 1, pl. XVII, fig. 2).

Stratigraphic range. - Mutabilis Zone, Mutabilis Subzone in northern Eurasia. Figured specimens from Northern Siberia are also known from the correlatives of the Askepta Subzone (Cymodoce Zone) below the first records of Aulacostephanoides, but this interval lacks other figured species of aulacostephanids that might provide clear biostratigraphical information. In Spitsbergen, the age of $Z$. (X.) thurrelli is also unclear. The level with those ammonites was tentatively assigned by Wierzbowski (1989) to the Xenostephanus horizon in the Mutabilis Zone, corresponding to the boundary beds of the Mutabilis Zone and Uralensis Subzone of the Evoluta Zone in the Khatanga Basin sensu Mesezhnikov (1984). This is the only aulacostephanid-bearing horizon in the Upper Kimmeridgian of Spitsbergen and Franz Josef Land (Rogov 2012). The most common species collected from this level in Franz Josef Land is Zenostephanus (Z.) sachsi (Mesezhnikov), which is also well recognized in Spitsbergen (Rogov 2014). A Zenostephanus-rich assemblage has also been recognized recently in a core drilled in the Norwegian part of the Barents Sea (A. Wierzbowski, pers. comm.) and reported from the Arkticheskaya-1 well in the Russian part of the Barents Sea (Chirva et al. 1990).

Geographical range. - England (Lincolnshire), Spitsbergen, Franz Josef Land, Western Siberia, Northern Siberia, British Columbia.

\section{Genus Zonovia Sasonov, 1960}

\section{Zonovia sp. A}

Figure 2E1, E2

2001 Perisphinctid ammonite, indet. - Evenchick et al., p. 55 .

Material. - GSC figured specimen 134804 from GSC Locality C-201802, McConnell Creek map area (Fig. 1).

Description. - The specimen studied consists of only $1 / 4$ of a probable outer whorl, possibly the terminal body chamber of a macroconch, as suggested by the character of the ribbing. All ribs are simple, rectiradiate to slightly prorsiradiate, and apparently crossed the venter without modification, although the deformation of the specimen makes this observation somewhat unclear. Eleven ribs are visible on the 1/4 of the whorl available. They are relatively thick, but distantly spaced, and the space between the ribs is about two times wider than their thickness. The ribs strengthen slightly toward the ventrolateral part of the flank, which is gently and evenly rounded across the entire height of the whorl.

Comparison. - The final body chambers of aulacostephanids from the Mutabilis Zone are mainly more or less smooth or exhibit split ribs. Taxa characterized by ultimate simplification of ribbing, as present in the British Columbia specimen, are uncommon. Some macroconchs of Zonovia (cf. Mesezhnikov 1984, pl. XXVIII, fig. 1, pl. XXIX, fig. 1) are characterized by simple ribs in the body chamber but differ from this specimen by having a smooth venter. An ammonite from the Subpolar Urals, referred by Mesezhnikov (1984, pl. XXIV, figs 1, 2) to as Rasenia borealis Spath, is closest to the ammonite illustrated here, but has slightly more distant ribs on the body chamber. The ammonite from the Urals differs significantly from $R$. borealis described from England and East Greenland, and is better referred to Zonovia. The character of the ribbing on the apparent outer whorl of the British Columbia specimen is also typical of that of some Eurasenia from the Askepta Subzone of the Cymodoce Zone, especially in some specimens of Eurasenia aulnisa Hantzpergue, 1989 (pl. 32, fig. 2), which, however, apparently have a very limited geographical range. It should be noted that some unpublished material from the cores drilled in Western Siberia yields an assemblage that is very similar to those described herein. It mainly consists of Zenostephanus (Xenostephanoides) cf. thurrelli (Arkell \& Callomon) co-occurring with simpleribbed body chambers of Zonovia sp. and uncommon Amoebites cf. modestum (Mesezhnikov \& Romm).

Stratigraphical range. - Cymodoce Zone; Mutabilis Zone, Mutabilis Subzone in northern Eurasia.

\section{Genus Rasenia Salfeld, 1913}

Rasenia ex gr. cymodoce (d'Orbigny, 1850)

Figures 2F1, F2, F3, G, 3A1, A2

2001 Aulacostephanus (?) sp. - Evenchick et al., p. 55, 74 (part).

2005 Aulacostephanus sp. - Evenchick \& Thorkelson, p. 205 (part). 


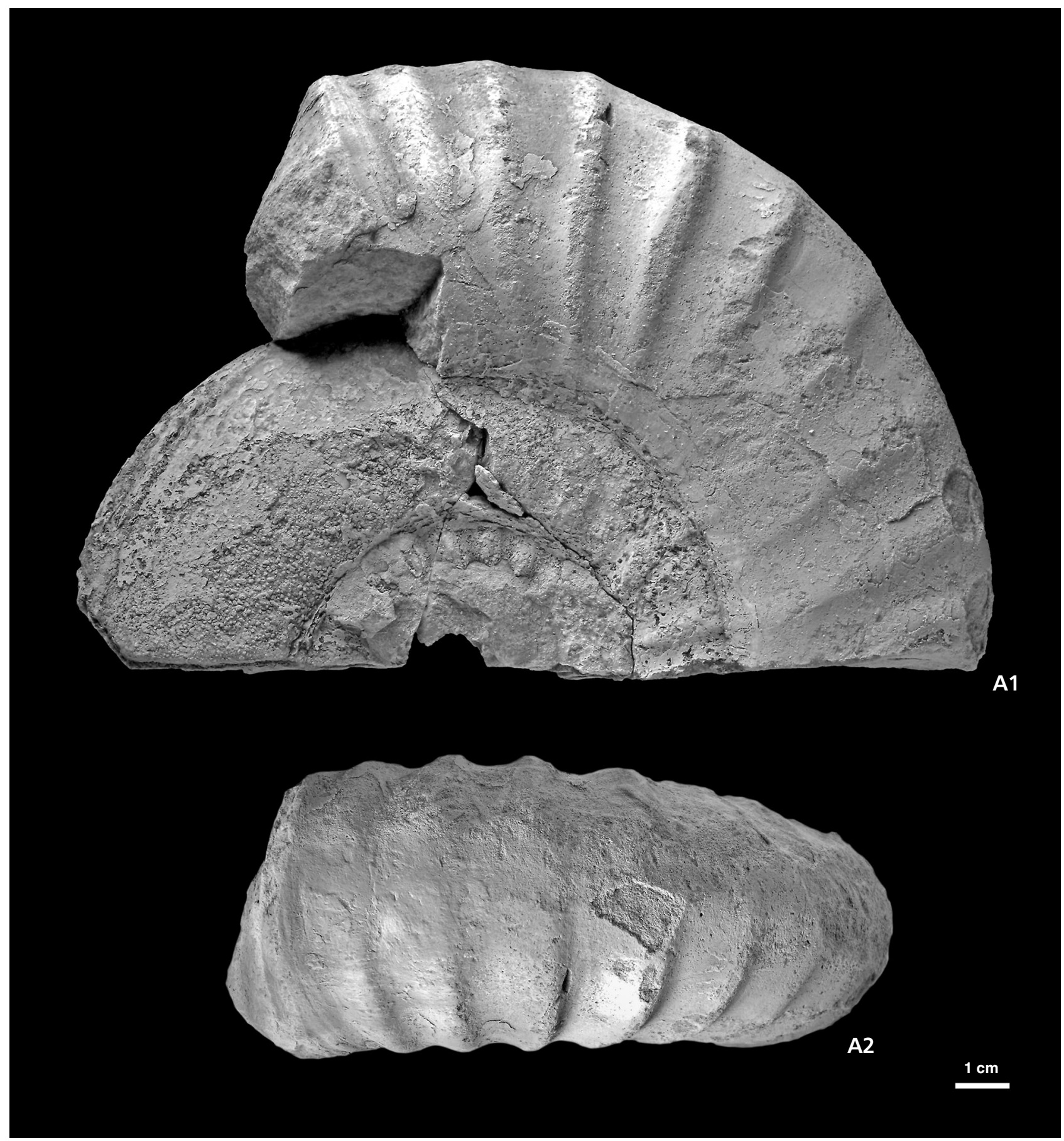

Figure 3. A1, A2 - Rasenia ex gr. cymodoce (d'Orbigny), from Cymodoce Zone in northwestern British Columbia. Lateral and ventral views of nearly full-grown GSC figured specimen GSC 134821 (same specimen as Fig. 2G) from GSC Locality C-175618 (same locality as Fig. 2C). The specimen is figured in actual size.

2012 Aulacostephanus sp. - Gagnon et al., Suppl. Data, p. 3 (OW3).

Material. - GSC figured specimens 134818 from GSC Locality C-201802 and 134821 from GSC Locality C-175618, from McConnell Creek and Spatsizi River map areas, respectively (Fig. 1).
Description. - One specimen (Fig. 2F1-F3) from the collection studied can be assigned to Rasenia ex gr. cymodoce (d'Orbigny). It is one half of a whorl of an immature specimen, and is one half of the size of another nearly fully grown specimen of apparently the same species (Figs 2G, 3A1, A2). The former, smaller, specimen shows 10 slightly prorsiradiate primaries per half a whorl. Each of these ribs 
is subdivided in the lower third of the whorl into three secondaries, which are not well connected with the primaries. The latter, larger, ammonite shows smooth outer whorls with primaries re-appearing at the terminal body chamber (Fig. 3A1) and is characterized by relatively involute inner whorls, with secondaries entirely covered by the overlying whorl.

Comparison. - Despite the incomplete preservation of the studied specimens, they bear some typical features that provide for their adequate comparison with Rasenia cymodoce (d'Orb.), the index of the Cymodoce Zone and cymodoce horizon.

Stratigraphical range. - Cymodoce Zone, cymodoce horizon in northwest Europe and the Russian Platform.

\section{Discussion}

The Late Jurassic faunas of western Canada are primarily Boreal in affinity (e.g. Taylor et al. 1984), and above the Middle Oxfordian, they are predominantly composed of species of the bivalve Buchia, so that detailed correlations with Standard European ammonite zonations are imprecise. Therefore, the rare occurrences of diagnostic ammonites, such as aulacostephanids, are extraordinarily important. The aulacostephanid specimens reported herein are not closely associated with cardioceratid ammonites such as Amoeboceras, although the latter do occur elsewhere in the same basin (Frebold \& Tipper 1970, fig. 8; Tipper \& Richards 1976; Evenchick et al. 2001, 2010), so that the enhanced biostratigraphic precision of such an association is not available in Canada, as it is in northern Eurasia.

The Bowser Basin faunas are generally different from those known from the southern regions of North America, but Late Jurassic Boreal faunas, including Buchia, are now found from the Arctic to at least as far south as northern California (Jones et al. 1969), Mexico (de la Mora et al. 2000, Pessagno et al. 2009), Cuba (Myczyński 1989) and the Russian Far East (Zakharov \& Rogov 2003). This is the later part of a global "Boreal Spread" recognized long ago (e.g. Arkell 1956, p. 610), the reasons for which are not yet known, but it coincides with incremental encroachment of seas over continental margins through the Jurassic globally (Hallam 1978, Haq et al. 1981). Stable isotope data suggest that the Kimmeridgian was among the warmest of the Jurassic ages (Price \& Rogov 2009, Dera et al. 2011), and such a conclusion is also supported by strong northward expansion of fossils with Tethyan affinities at this time (Rogov \& Zakharov 2004, Rogov et al. 2009). Perhaps the Kimmeridgian episode of the "Boreal Spread" can be explained by either re-organization of water circulation caused by Pangea breakup, or by the influence of shortterm cooling events.
It should be noted that co-occurrences of the Boreal bivalve Buchia and Pacific/Mediterranean ammonites are very typical in the uppermost Jurassic of some low-latitude sections of the Western and Eastern Pacific (Zakharov \& Rogov 2003, 2004). Such a distributional pattern of bivalves and ammonites might be explained by differential scattering of buchiid and ammonite larvae or adults by ocean currents; for example, these bivalves might have inhabited the relatively cold sea floor, while a warmer upper part of the water column was characterized by ammonites of different palaeobiogeographic affinities.

The aulacostephanid ammonites from British Columbia provide unequivocal evidence for an interval around the Lower/Upper Kimmeridgian boundary. However, the separation of faunas that provides the basis for the Cymodoce and the Mutabilis zones on either side of the boundary in Northwest Europe, is not seen in the much more limited western Canadian material.

The base of the Mutabilis Zone is commonly considered now to be placed at the Lower/Upper Kimmeridgian boundary (e.g. Gradstein et al. 2012, p. 746). It is marked by the appearance of Aulacostephanoides (base of the Mutabilis Zone sensu gallico) or Rasenioides (base of the Askepta Subzone and the Mutabilis Zone sensu anglico) within a single ammonite lineage. Both these boundaries are unclear using aulacostephanid microconchs [Prorasenia - Rasenioides (Rasenioides) - Aulacostephanoides (Aulacostephanites)], but are well recognized by changes in the macroconchs (Rasenia - Rasenioides (Semirasenia) - Aulacostephanoides (Aulacostephanoides)). We accept the Lower/Upper Kimmeridgian boundary as the base of the Mutabilis Subzone, because it is better traced in the Arctic region by the appearance of Aulacostephanoides, while Semirasenia is characterized by a restricted geographical distribution and is unknown in Boreal areas. The Zenostephanus-rich level is here considered to correspond to the Mutabilis Subzone. In spite of the presence of the oldest (uncommon) Zenostephanus in the upper Cymodoce Zone (Wierzbowski \& Rogov 2013), mass occurrences of this species are known only from the Mutabilis Zone s.s., and new records of Zenostephanus (Z.) sachsi (Mesezhnikow) from the Russian Platform and Polish lowland confirm this conclusion.

In all Arctic Eurasian areas, these two faunas are clearly and consistently separated. However, in the western Canadian collections, Rasenia closely resembling European material from the Cymodoce Zone (cymodoce horizon), and Zenostephanus most similar to correlatives of the Zenostephanus sachsi horizon of Arctic Eurasia, co-occur in two widely separated Bowser Basin localities. Matrix lithologies are consistent within each of these Canadian collections (C-201802 and C-175618), making it unlikely that either of them was collected from more than a single horizon. It also seems unlikely that the association of these 
Mikhail A. Rogov \& Terry P. Poulton - Aulacostephanid ammonites from the Kimmeridgian (Upper Jurassic) of British Columbia

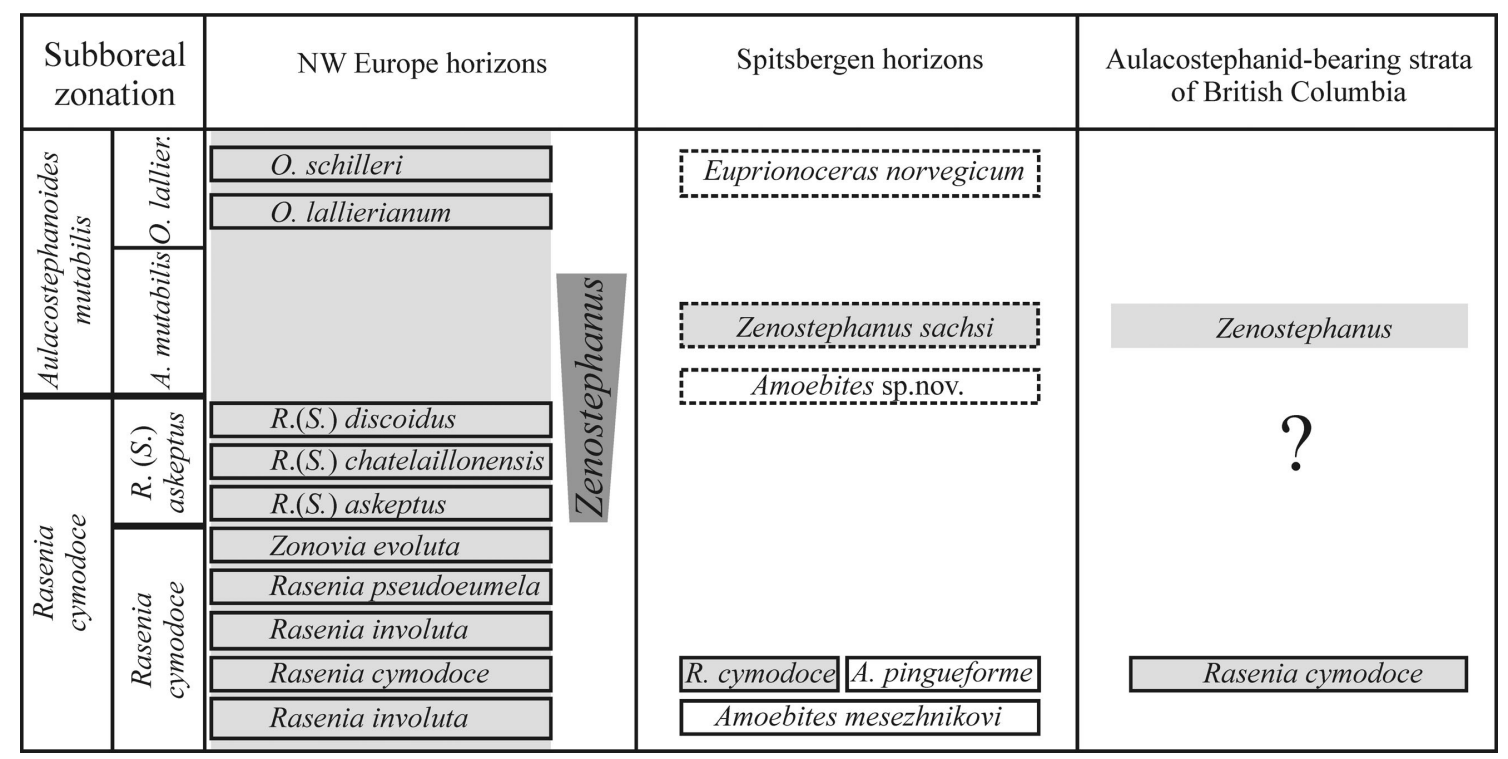

Figure 4. Composite succession of biohorizons in the Cymodoce and Mutabilis zones of NW Europe and position of the Lower/Middle Kimmeridgian boundary (after Birkelund et al. 1983, Hantzpergue 1989, with additions), correlation of this succession with those of Spitsbergen (Rogov 2014) and the implied correlations of the aulacostephanid-bearing strata in British Columbia (shown by light-grey pattern). The biohorizons of the Mutabilis Subzone recognized by Hantzpergue $(1979,1989)$ based on Aulacostephanoides succession are not shown, as they do not correspond to the ranges of index-species and were not supported by figures of these taxa. The pseudoeumela horizon (type section: Le Havre, Normandy, lower part of limestones with Harpagodes, bed VI 2 in Samson et al. 1996) is proposed now as the Subboreal equivalent of the Eurasenia aulnisa horizon of Aquitaine; it is characterized by the presence of Rasenia berryeri (Lesueur), R. lexoviensis Hantzpergue and Rasenia pseudoeumela (Tornquist), while corresponding microconchs belong to Rasenioides. The Canadian faunas, indicated in this figure with separate higher and lower faunal elements, in fact co-occur so that their age implications are somewhat unclear.

two apparently different ammonite faunas would be due to either condensed deposition or removal at a cryptic unconformity, over such a large area in a succession generally characterized by rapid clastic sedimentation. However, the very wide distribution of Zenostephanus might suggest a relative transgressive episode at the beginning of the Late Kimmeridgian, below which a certain amount of cryptic regional erosion or non-deposition in Bowser Basin cannot be ruled out. Correlation of the aulacostephanid faunas of British Columbia with the regionally well-developed and limited ranges of the most similar species in the NW European (Subboreal) composite and the Boreal (Spitsbergen) successions is shown in Fig. 4. Nevertheless, this does not completely preclude the possibility that the Canadian collections represent intermediate stratigraphic levels between the suggested Eurasian correlatives, the cymodoce and sachsi horizons. There is an interval at the top of the Cymodoce Zone in northern Eurasia, where Zenostephanus, Rasenia and Zonovia, may co-occur, but there is no particular reason to suggest this correlation for the Canadian co-occurrences with confidence. Such co-occurrence is most clear in the Uralensis Subzone of the Evoluta Zone in northern Siberia (Mesezhnikov 1984), which corresponds to the Askepta Subzone in Europe (Wierzbowski \& Rogov 2013). It should be noted that Rasenia from the Evoluta Subzone belongs to endemic taxa, which are un- known outside Siberia and differ also from Rasenia recorded in British Columbia.

The faunal mix in British Columbia, with representatives of both Boreal and Subboreal provinces, might be explained by the sea-level highstand indicated by Hallam (1978) and Haq et al. (1981). Close dependence of ammonite evolution and migration events with sea level oscillations in the Kimmeridgian were recognized by Atrops \& Ferry (1987), Hantzpergue (1995) and Gygi (2012), who noted significant sea-level rise during the middle of the Mutabilis Zone and its submediterranean correlatives.

Aulacostephanidae is a short-lived ammonite family, Late Oxfordian and Kimmeridgian in age, which inhabited, for the most part, a narrow ecotone region between two major Super-realms - Tethys-Panthalassa and Pan-boreal (Zakharov \& Rogov 2003), usually considered as a separate Subboreal or Atlantic-Boreal Province or Realm. To the south and north from this transitional area, aulacostephanids are uncommon or restricted to a few stratigraphic levels. Very rare aulacostephanids are reported from the Submediterranean, and especially from the Mediterranean, areas. For example, aulacostephanid records from the Acanthicum Zone of the famous Mount Crussol site (SE France) comprise only $0.5 \%$ of all ammonites (Baudouin et al. 2011), and only one (unfigured) specimen 
of a true Aulacostephanus is known from the Kimmeridgian of Mexico (Villaseñor et al. 2000). In the high-latitude Arctic, aulacostephanids are also rare. They are entirely missing in the Nordvik section (northern central Siberia), where the ammonite succession consists of cardioceratids and the Boreal oppeliid genus Suboxydiscites only (Rogov \& Wierzbowski 2009, Wierzbowski \& Rogov 2013). Aulacostephanids are unknown from east of the Anabar River in northern Yakutia (Siberia). Only two occurrences of Aulacostephanus were reported from the North-East of Russia (Kolyma River Basin) and the Russian Far East (Gurin 1959, Krasnyi 1960), but these ammonites are missing in the collections and were not figured, described or reported subsequently

Previous aulacostephanid records from Mexico, Peru and the Asian Pacific region are enigmatic, mistaken, or very rare and poorly documented. Ammonites described as Aulacostephanus zacatecanus by Burckhardt (1906) from the Mexican Kimmeridgian became the type species of Pararasenia, which is now considered to be a homoeomorph of true aulacostephanids (see Enay \& Mangold 1982, Birkelund et al. 1983). Besides this homoeomorph (of which only a single specimen is known to date), a single specimen of true Aulacostephanus sp. was recorded from the Upper Kimmeridgian ( Eudoxus Zone) in Mexico (Villaseñor et al. 2000). In addition to these suspected aulacostephanid occurrences, a few other doubtful aulacostephanids have been reported from the Lower Kimmeridgian of Mexico. These are Pictonia (Colladites) a subgenus based on a Mexican type species described by Cantú Chapa (1967), and Rasenia aff. (Rasenoides) striolaris (Reinecke), reported from a unit that also contains Ataxioceras in Eastern Mexico (Cantú Chapa 1969). Pictonia (Colladites), however, differs significantly from true Pictonia by its simple ribbing on the inner whorls, and it should be considered as a separate genus, possibly belonging to Ataxioceratidae. The specimen of Rasenia mentioned by Cantú Chapa (1969) has been figured by him under the name Rasenia aff. (Rasenioides) (Cantú Chapa 1992, pl. 1, fig. 10). This crushed and partially preserved ammonite, in our opinion, cannot be ascribed to the aulacostephanids and, as it closely resembles co-occurring Ataxioceras (loc. cit., pl. 1, fig. 1, 3, 9, 14, 19), this specimen perhaps also belongs to Ataxioceratidae. It should be noted that the Mexican Amoeboceras reported by Imlay (1980) could be based on an erroneous determination of Hybonoticeras (as figured in Burckhardt 1906) by Ziegler (1962). Burckhardt's ammonites were later confirmed as Hybonoticeras (Schweigert et al. 1996). Amoeboceras records were also mentioned by Beauvais \& Stump (1976) from the Pozo de Serna area in Mexico, but later revision of these ammonites has shown that they were determined erroneously and belong to Lower Jurassic taxa (Linares et al. 1997). In the opinion of A.B. Villaseñor (pers. comm., May
2013), boreal ammonites are absent in the Kimmeridgian of Mexico.

Aulacostephanus reported from the Kimmeridgian of southern Peru (Vicente 1981) was erroneously determined (A. von Hillebrandt, pers. comm. 2012). Aulacostephanid occurrences mentioned from the western Pacific (northern China and Japan) need to be re-considered. Japanese "aulacostephanids" are preserved as crushed molds and the nature of their ventral region remains unclear. The large specimen figured by Takahashi (1969, pl. 16, fig. 1) shows the typical rib pattern of Lithacoceras or Euvirgalithacoceras with dense ribs in the inner whorls, which changed to more distant thick primaries and very numerous secondaries in the outer whorl. Two small specimens figured by Matsumoto \& Hirata (1970, fig. 2) are characterized by the presence of fascipartite to virgatotome ribs with a high rib ratio and probably belong to ataxioceratids such as submediterranean Ataxioceras or the Indo-West Pacific Stevensia-Nepalites group. The few ammonites from northern China (Heilongjiang) assigned by Li (1997) to Pictonia and Rasenia (loc. cit., pl. 1, fig. 1, 2, 5-7) lack any ribbing and do not belong to the Perisphinctoidea Superfamily.

The aulacostephanid records in British Columbia are separated from other confirmed aulacostephanid occurrences by great distances (Fig. 5). Nevertheless, their possible migrational pathway can be tentatively traced. Because their abundance in northwestern and northern Eurasia suggests their center of origin and evolution there, we propose possible migration of these boreal and subboreal taxa out of those areas into Arctic and western Canada. They may have moved into the northeastern ancestral Pacific Ocean under the influence of currents that, in the later part of their trajectory, had a strong component southward along the northwestern North American margin. This proposal takes into account reports of aulacostephanid ammonites from Arctic Canada (Rasenia in Tan \& Hills 1978), the common presence of Amoeboceras and related cardioceratids in British Columbia (Tipper \& Richards 1976; Evenchick et al. 2001, 2010), and California (Imlay 1980), as well as the constant abundance of the boreal bivalve Buchia along the western coast of North America.

\section{Conclusions}

The aulacostephanid ammonites Zenostephanus, Rasenia, and Zonovia occur rarely in samples collected during geological mapping programs in the western Cordillera of British Columbia, western Canada, in the northern part of the Bowser Basin. This sedimentary basin is represented by a thick sequence of Middle Jurassic through Early Cretaceous clastic rocks deposited upon the Stikinia exotic terrane. Stikinia is one of many terranes that were amalgamated and accreted to western North America (or Laurasia) 


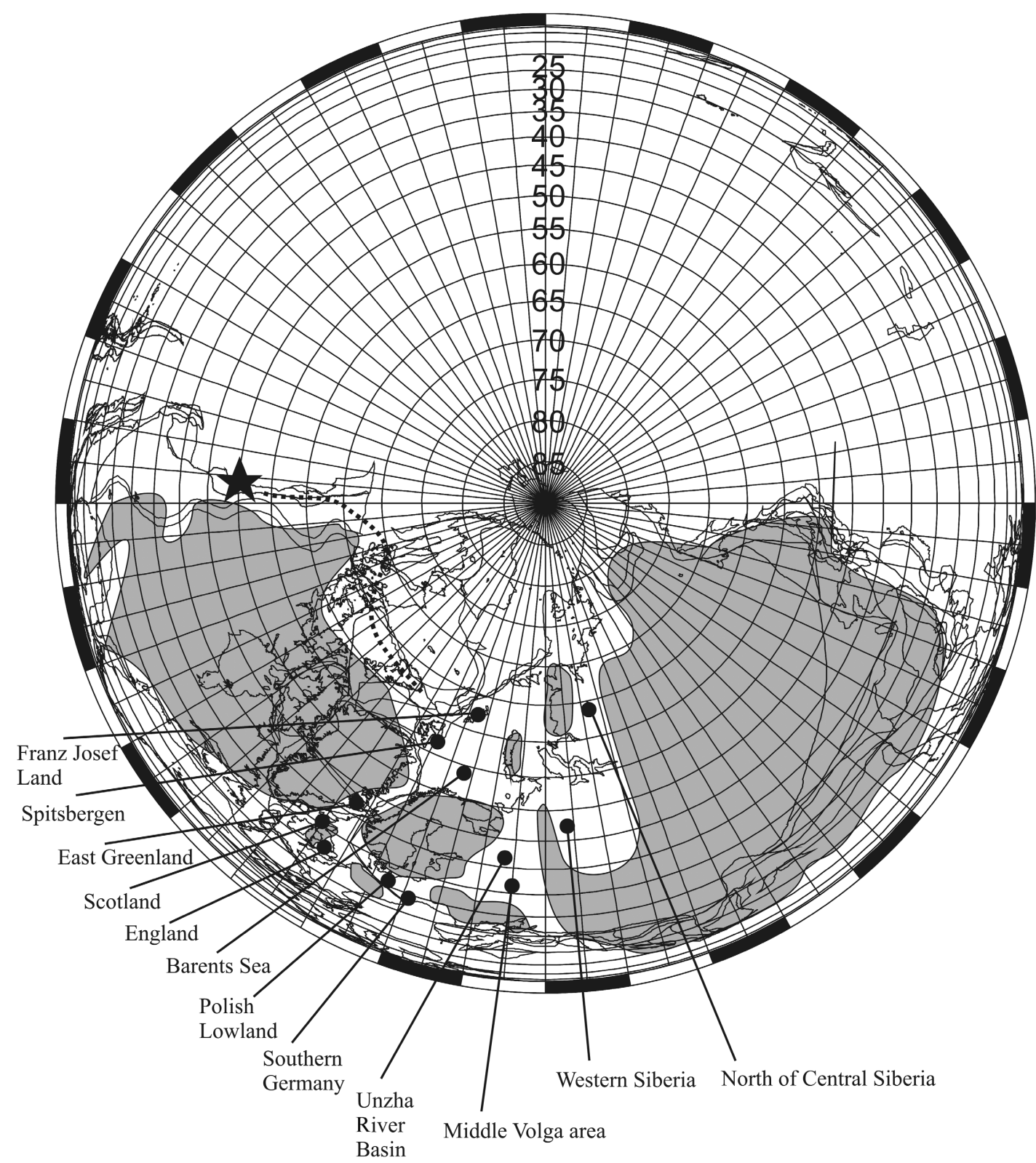

Figure 5. Zenostephanus distribution and possible migrational pathway of this genus to British Columbia. North Polar geodynamic reconstruction on 150 Mya from www.osdn.de. Palaeogeography is simplified. Zenostephanus occurrences marked by black circles. Occurrence in British Columbia is marked by star at the left side of the map.

during the Mesozoic, but there is neither an agreement on the timing or on the nature of these tectonic processes, or on the original palaeogeographic disposition of this terrane during the Kimmeridgian. The ammonites, described and illustrated for the first time in this report, indicate correlations with part or parts of the Early and Late Kimmeridgian Cymodoce and Mutabilis, or possibly Askepta, zones of northwest Europe. In two out of four of the fossil localities available, Zenostephanus and Rasenia co-occur, so that the age and correlation of the western Canada material with respect to the better-known European zonation is imprecise. These boreal and subboreal ammonites, well repre- sented in northern Eurasia, perhaps migrated into the northeast palaeo-Pacific area down the northwest side of Laurasia from Arctic areas during a major transgressive period. In Eurasia, Zenostephanus is known from southern Germany, European part of Russia, Polish lowland, East Greenland, Spitsbergen, Franz Josef Land, Barents Sea shelf, and western and northern Siberia. Its migration into British Columbia is approximately correlative with a long-term transgression that also led to expansion of the Submediterranean ammonite genus Crussoliceras through the Submediterranean and subboreal areas slightly before Zenostephanus. 


\section{Responsibilities and acknowledgements}

The taxonomic portions of this report are by Rogov, the geological portion by Poulton; both authors contributed to the palaeobiogeographic and correlation discussions. This study has been supported by RFBR grants 12-05-00386 and Program No. 1 of Earth Science Division of RAS (M.R.). It is a contribution of the Geological Survey of Canada (GSC). Glen Edwards produced the photographs and plates, and Jamel Joseph supplied maps with the historical localities plotted. We also thanks Jingeng Sha (Nanking, China) for the PDF of the rare Chinese article by Li (1997), as well as Abelardo Cantú Chapa and Ana Bertha Villaseñor (Mexico) for information and references on Mexican aulacostephanid records. We thank Horacio Parent, Margot McMechan, and an anonymous reviewer for their valuable comments.

\section{References}

ARKELL, W.J. 1956. Jurassic Geology of the World. 806 pp. Oliver and Boyd Ltd, London.

Arkell, W.J. \& Callomon, J.H. 1963 Lower Kimmeridgian ammonites from the drift of Lincolnshire. Palaeontology 6, 216-245.

Atrops, F. \& Ferry, S. 1987. Les glissements sous-marins kimméridgiens du bassin subalpin, témoins possibles de variations eustatiques négatives. Géologie Alpine, Mémoirs, hors séries 13, 179-185.

Baudouin, C., Boselli, P. \& Bert, D. 2011. The Oppeliidae of the Acanthicum Zone (Upper Kimmeridgian) from Mount Crussol (Ardèche, France): ontogeny, variability and dimorphism of the genera Taramelliceras and Streblites (Ammonoidea). Revue de Paléobiologie 30, 619-684.

Beauvais, L. \& Stump, T.E. 1976. Corals, molluscs and paleogeography of late Jurassic strata of the Cerro Pozo Serna, Sonora, Mexico. Palaeogeography, Palaeoclimatology, Palaeoecology 19, 275-301. DOI 10.1016/0031-0182(76)90030-4

Birkelund, T. \& Callomon, J.H. 1985. The Kimmeridgian ammonite faunas of Milne Land, central East Greenland. Grønlands Geologiske Undersøgelse Bulletin 153, 5-56.

Birkelund, T., Callomon, J.H., Clausen, C.K., Nøhr Hansen, H. \& Salinas, I. 1983. The Lower Kimmeridge Clay at Westbury, Wiltshire, England. Proceedings of the Geologists' Association 94(4), 289-309.

BuRCKHARDT, C. 1906. La faune Jurassique de Mazapil avec un appendice sur les fossiles du Crétacique inférieur. Boletín del Instituto Geológico de México 23, 5-216.

Callomon, J.H., Donovan, S.K. \& Van Den Hoek Ostende, L. 2009. Zenostephanus, a new name for the genus Xenostephanus Arkell and Callomon, 1963 (Mollusca, Cephalopoda), preoccupied by Xenostephanus Simpson, Minoprio and Patterson, 1962 (Mammalia). Palaeontology 52, 671-672. DOI 10.1111/j.1475-4983.2009.00863.x

Cantú Chapa, A. 1967. Se propone Colladites subgen nov. (Am- monoidea), del Kimmeridgiano Inferior. Ingenieria Petrolera 7(2), 5-9.

Cantú Chapa, A. 1969. Estratigrafía del Jurásico Medio-Superior del subsuelo de Poza Rica, Ver. (Area de Soledad-Miquetla). Revista del Instituto Mexicano del Petróleo 1(1), 3-9.

Cantú Chapa, A. 1992. El Kimeridgiano Inferior del subsuelo en el Este de México. Revista Mexicana del Petróleo 334, 30-35.

Chirva, S.A., Morakhovskaya, E.D., Kulikova, N.K., FedoRova, V.A. \& Yakovleva, S.P. 1990. Stratigraphy of the Triassic and Jurassic deposits of the Barents Sea, 15-30. In Geological structure and oil-and-gas potential of Arctic Islands. Collection of scientific papers. VNIGRI, Leningrad. [in Russian]

De la Mora, A., Olóriz, F. \& González-Arreola, C. 2000. 'Autochtonous' bivalve assemblages and palaeoecologic interpretation in the Upper Jurassic-Lower Cretaceous La Caja Formation from the Cañon de San Matías (Zacatecas, México). Comptes rendus de l'Académie des sciences, Série 2, Sciences de la terre et des planètes 331, 741-747.

Dera, G., Brigaud, B., Monna, F., Laffont, R., Pucéat, E., Deconinck, J.-F., Pellenard, P., Joachimski, M.M. \& DurLET, C. 2011. Climatic ups and downs in a disturbed Jurassic world. Geology 39, 215-218. DOI 10.1130/G31579.1

Enay, R. \& Mangold, C. 1982. Dynamique biogéographique et évolution des faunes d'Ammonites ou Jurassique. Bulletin de la Société Géologique de la France, 7 e série 24, 1025-1046.

EvenCHICK, C.A. 1991. Geometry, evolution, and tectonic framework of the Skeena fold belt, north-central British Columbia. Tectonics 10, 527-546. DOI 10.1029/90TC02680

Evenchick, C.A., McMechan, M.E., McNicoll, V.J. \& Carr, S.D. 2007. A synthesis of the Jurassic-Cretaceous tectonic evolution of the central and southeastern Canadian Cordillera: exploring links across the orogen. Geological Society of America, Special Publication 433, 117-145.

Evenchick, C.A., Poulton, T.P. \& McNicoll, V.J. 2010. Nature and significance of the diachronous contact between the Hazelton and Bowser Lake groups (Jurassic), north-central British Columbia. Bulletin of Canadian Petroleum Geology 58, 235-267. DOI 10.2113/gscpgbull.58.3.235

Evenchick, C.A., Poulton, T.P., Tipper, H.W. \& Braidek, I. 2001. Fossils and facies of the northern two-thirds of the Bowser Basin, British Columbia. Geological Survey of Canada, Open File 3956, 1-103. DOI 10.4095/212067

Evenchick, C.A. \& Thorkelson, D.J. 2005. Geology of the Spatsizi River map area, north-central British Columbia. Geological Survey of Canada, Bulletin 577, 1-276.

Frebold, H. 1930. Verbreitung und Ausbildung des Mesozoikums in Spitsbergen. Skrifter om Svalbard og Ishavet 31, $1-127$.

Frebold, H. \& TiPPER, H.W. 1970 Status of the Jurassic in the Canadian Cordillera of British Columbia, Alberta, and southern Yukon. Canadian Journal of Earth Sciences 7, 1-21. DOI 10.1139/e70-001

Gagnon, J.-F., Barresi, T., Waldron, J.W.F., Nelson, J.L., Poulton, T.P. \& CoRdey, F. 2012. Stratigraphy of the upper Hazelton Group and the Jurassic evolution of the Stikine terrane, British Columbia. Canadian Journal of Earth Sciences 49, 1027-1052. DOI 10.1139/e2012-042 
Gagnon, J.-F., Evenchick, C.A., Waldron, J.W.F., Cordey, F. \& Poulton, T.P. 2009. Jurassic subsidence history of the Hazelton Trough-Bowser Basin in the area of Todagin Mountain, north-central British Columbia, Canada. Bulletin of $\mathrm{Ca}$ nadian Petroleum Geology 57, 1-19.

DOI 10.2113/gscpgbull.57.4.430

Gradstein, F., OGG, J., Schmitz, M. \& OGG, G. (eds) 2012. The Geological Time Scale 2012, Volume 1. 1144 pp. San Francisco, CA, Elsevier.

GreIG, C.J. 1992. Fieldwork in the Oweegee and Snowslide ranges and Kinskuch Lake area, northwestern British Columbia. Geological Survey of Canada Paper 92-1A, 145-155.

Greig, C.J. \& Evenchick, C.A. 1993. Geology of Oweegee dome (geochemistry and paleontology), Delta Peak (104A/12) and Taft Creek (104A/11W) map areas, northwestern British Columbia. Geological Survey of Canada, Open File 2688. DOI 10.4095/184197

Greig, C.J., Gehrels, G.E., Anderson, R.G. \& Evenchick, C.A. 1991. Possible transtensional origin of the Bowser Basin, British Columbia. Geological Society of America, Abstracts with Programs 23(2), 30.

GuRIN, G.F. 1959. Stratigraphy of the Jurassic deposits of the Taskan-Lyglykhtakh area, 287-290. In Trudy mezhvedomstvennogo soveshchaniya po razrabotke unifitsirovannykh stratigraficheskikh skhem severo-vostoka SSSR 1957 g. Doklady. Magadanskoe knizhnoe izdatel'stvo, Magadan. [in Russian]

GyGI, R. 2012. Quantitative Geology of Late Jurassic Epicontinental Sediments in the Jura Mountains of Switzerland. 216 pp. Springer, Basel. DOI 10.1007/978-3-0348-0136-2

Haggart, J.W., Enkin, R.J. \& Monger, J.W.H. 2006. Paleogeography of the North American Cordillera: evidence for and against large-scale displacements. Geological Association of Canada, Special Paper 46, 1-429.

Hall, R.L., Poulton, T.P. \& Diakow, L. 1991. Lower Bajocian (Middle Jurassic) ammonites and bivalves from the Whitesail Lake area, West-central British Columbia. Geological Survey of Canada, Bulletin 412, 133-167. DOI 10.4095/132682

Hallam, A. 1978. Eustatic cycles in the Jurassic. Palaeogeography, Palaeoclimatology, Palaeoecology 23, 21-32. DOI 10.1016/0031-0182(78)90079-2

HantzPergue, P. 1979. Biostratigraphie du Jurassique supérieur nord-aquitain. Bulletin de la Société géologique de la France, Série 7 21, 715-725.

HantzPergue, P. 1989. Les Ammonites Kimméridgiennes du haut-fond d'Europe occidentale. Biochronologie, Systématique, Evolution, Paléobiogéographie. 428 pp. Cahiers de Paléontologie, édit. C.N.R.S., Paris.

HantZPergue, P. 1995. Faunal trends and sea level changes: biogeographic patterns of Kimmeridgian ammonites on the Western European Shelf. Geologische Rundschau 84, 245-254. DOI 10.1007/s005310050003

HaQ, B.U., Hardenbol, J. \& Vail, P.R. 1987. Chronology of fluctuating sea levels since the Triassic. Science 235, 1156-1167. DOI 10.1126/science.235.4793.1156

Harrison, J.C., Wall, J.H., Brent, T.A., Poulton, T.P. \& Davies, E.H. 2000. A Jurassic Rift System in the Canadian Arctic Islands, 427-436. In Hall, R.L. \& Sмith, P.L. (eds) Advances in Jurassic Research. GeoResearch Forum 6. Trans Tech Publications, Uetikon-Zurich.
Hillebrandt, A. von, Smith, P., Westermann, G.E.G. \& CalloMON, J.H. 1993 Ammonite zones of the circum-Pacific region, 247-272. In Westermann, G.E.G. (ed.) The Jurassic of the Circum-Pacific. University Press, Cambridge.

IMLAY, R.W. 1980. Jurassic paleobiogeography of the conterminous United States in its continental setting. United States Geological Survey Professional Paper 1062, 1-134.

JELETZKY, J.A. 1984. Jurassic-Cretaceous boundary beds of western and Arctic Canada and the problem of the TithonianBerriasian stages in the boreal realm, 175-256. In WESTERMANN, G.E.G. (ed.) Jurassic-Cretaceous biochronology and biogeography of North America. Geological Association of Canada Special Paper 27.

Jones, D.L., BAiley, E.H. \& ImLAy, R.W. 1969. Structural and stratigraphic significance of the Buchia Zones in the Colyear Springs-Paskenta Area, California. United States Geological Survey Professional Paper 647-A, 1-24.

KRASNYI, L.I. 1960. Geology and mineral resources of Western Priokhotie. Trudy Vsesoyuznogo geologicheskogo instituta, novaya seriya 34, 1-161. [in Russian]

LI, W. 1997. The Jurassic system of Continental Oceanic Facies in Heilongjiang Province. Heilongjiang Geology 8(1), 1-10. [in Chinese with English summary]

Linares, A., Olóriz, F. \& Villaseñor, A.B. 1997. Presencia de Tropidoceras flandrini (Dumortier) en Pozo de Serna, Sonora (México). Revista Española de Paleontología 12(2), 257-264.

MaLinowsKa, L. 1986. Paleozoogeography and paleoecology of the Lower Kimmeridgian of Poland. Bulletin of the Polish Academy of Sciences, Earth Sciences 34, 165-173.

Marsden, H. \& Thorkelson, D.J. 1992. Geology of the Hazelton Volcanic Belt in British Columbia: Implications for the Early to Middle Jurassic Evolution of Stikinia. Tectonics 11, 1266-1287. DOI 10.1029/92TC00276

Matsumoto, T. \& Hirata, M. 1970. Probably Jurassic ammonite from the Kuraoka area, Kyushu. Journal of the Geological Society of Japan 76, 223-224. [in Japanese]

DOI 10.5575/geosoc.76.223

MeseZhnikov, M.S. 1969. Kimmeridgian ammonites, 99-124. In SAKS, V.N. (ed.) Opornyi razrez verkhneyurskikh otlozhenii basseina $r$. Khety (Khatangskaya vpadina). Nauka, Leningrad. [in Russian]

MESEZHNIKOv, M.S. 1984. Kimeridzhskii i volzhskii yarusy severa SSSR. 224 pp. Nedra, Leningrad. [in Russian]

MYCZYŃSKI, R. 1989. Ammonite biostratigraphy of the Tithonian of western Cuba. Annales Societatis Geologorum Poloniae 59, 43-145.

Nokleberg, W.J., Pafenov, L.M., Monger, J.W.H., Norton, I.O., Khanchuk, A.I., Stone, D.B., Scotese, C.R., Scholl, D.W. \& FujitA, K. 2001. Phanerozoic tectonic evolution of the circum-North Pacific. United States Geological Survey Professional Paper 1626, 1-133.

Pessagno, E.A., Jr., Cantú-Chapa, A., Martinson, J.M., Meng, X. \& KariminiA, S.M. 2009. The Jurassic-Cretaceous boundary: new data from North America and the Caribbean. Stratigraphy 6(3), 185-262.

Poulton, T.P., Detterman, R.L., Hall, R.L., Jones, D.L., PeterSON, J.A., SMith, P., TAYlor, D.G., TipPeR, H.W. \& WesterMANN, G.E.G. 1993. Western Canada and United States, 
29-92. In Westermann, G.E.G. (ed.) The Jurassic of the Circum-Pacific. University Press, Cambridge.

Poulton, T.P., Hall, R.L. \& Callomon, J.H. 1994. Ammonite and bivalve assemblages in Bathonian through Oxfordian strata of northern Bowser Basin, northwestern British Columbia, Canada. Geobios Mémoire Special 17, 415-421. DOI 10.1016/S0016-6995(94)80162-2

Price, G.D. \& Rogov, M.A. 2009. An isotopic appraisal of the Late Jurassic greenhouse phase in the Russian Platform. Palaeogeography, Palaeoclimatology, Palaeoecology 273, 41-49. DOI 10.1016/j.palaeo.2008.11.011

Repin, Y.S., Fedorova, A.A., Bystrova, V.V., Kulikova, N.K. \& Polubotko, I.V. 2007. Mesozoic of the Barents sea sedimentological basin, 112-161. In KiRichKovA, A.V. \& DMiTRIEVA, T.V. Stratigrafiya i ee rol' v razvitii neftegazovogo kompleksa Rossii. VNIGRI, Saint-Petersburg. [in Russian]

Rogov, M.A. 2012. Latitudinal gradient of taxonomic richness of ammonites in the Kimmeridgian-Volgian in the northern hemisphere. Paleontological Journal 46(2), 148-156. DOI 10.1134/S0031030112020104

Rogov, M.A. 2014. Ammonites and infrazonal biostratigraphy of the Kimmeridgian of Spitsbergen. Norwegian Petroleum Directorate Bulletin 1, 43-55.

Rogov, M. \& WierzBowski, A. 2009. The succession of ammonites of the genus Amoeboceras in the Upper Oxfordian-Kimmeridgian of the Nordvik section in northern Siberia. Volumina Jurassica 7, 147-156.

Rogov, M., Zakharov, V. \& Kiselev, D. 2009. Molluscan immigrations via biogeographical ecotone of the Middle Russian Sea during the Jurassic. Volumina Jurassica 6, 143-152.

Samson, Y., Lepage, G., Hantzpergue, P., Guyader, J., SaintGermès, M., Baudin, F. \& Bignot, G. 1996. Révision lithostratigraphique et biostratigraphique du Kimméridgien de la région havraise (Normandie). Géologie de la France 3, 3-19.

Schweigert, G., Krishna, J., Pandey, B. \& Pathak, D.B. 1996. A new approach to the correlation of the Upper Kimmeridgian Beckeri Zone across the Tethyan Sea. Neues Jahrbuch für Geologie und Paläontologie, Abhandlungen 202, 345-373.

TAKAHASHI, H. 1969. Stratigraphy and Ammonite Fauna of the Jurassic System of the Southern Kitakami Massif, Northeast Honshu, Japan. Science reports of the Tohoku Imperial University, $2^{\text {nd }}$ series, Geology 41, 1-93.
TAN, J.T. \& HiLls, L.V. 1978. Oxfordian-Kimmeridgian dinoflagellate assemblage, Ringnes Formation, Arctic Canada. Current Research, Part C, Geological Survey of Canada, 78-1C, 63-73.

Taylor, D.G., Callomon, J.H., Hall, R., Smith, P.L., TipPer, H.W. \& Westermann, G.E.G. 1984. Jurassic ammonite biogeography of western North America: the tectonic implications, 121-141. In WestermanN, G.E.G. (ed.) Jurassic-Cretaceous biochronology and biogeography of North America. Geological Association of Canada Special Paper 27.

TIPPER, H.W. \& RichARDS, T.A. 1976. Jurassic stratigraphy and history of north-central British Columbia. Geological Survey of Canada, Bulletin 270, 1-73. DOI 10.4095/103065

Vicente, J.C. 1981. Elementos de la estratigrafía Mesozoica Surperuana, 319-351. In Volkheimer, W. \& Musacchio, E. (eds) Cuencas sedimentarias del Jurásico y Cretácico de América del Sur, t. 1. Buenos Aires.

Villaseñor, A.B., Olóriz, F. \& GonZÁlez-Arreola, C. 2000. Recent advances in Upper Jurassic (Kimmeridgian-Tithonian) ammonite biostratigraphy of North-Central Mexico based on recently collected ammonite assemblages, 249-262. In Hall, R.L. \& Sмith, P.L. (eds) Advances in Jurassic Research. GeoResearch Forum 6. Trans Tech Publications, Uetikon-Zurich.

WierzBowski, A. 1989. Ammonites and stratigraphy of the Kimmeridgian at Wimanfjellet, Sassenfjorden, Spitsbergen. Acta Palaeontologica Polonica 34, 355-378.

Wierzbowski, A. \& Rogov, M.A. 2013. Biostratigraphy and ammonites of the Middle Oxfordian to lowermost Upper Kimmeridgian in northern Central Siberia. Russian Geology and Geophysics 54, 1083-1102. DOI 10.1016/j.rgg.2013.07.021

ZAKHAROv, V.A. \& Rogov, M.A. 2003. Boreal-Tethyan mollusk migrations at the Jurassic-Cretaceous boundary time and biogeographic ecotone position in the Northern Hemisphere. Stratigraphy and Geological Correlation 11, 152-171.

Zakharov, V.A. \& Rogov, M.A. 2004. The Boreal-Tethyan biogeographical mollusk ecotone in Europe during the Jurassic-Cretaceous transition. Rivista Italiana di Paleontologia e Stratigrafia 110(1), 339-444.

ZiEgLER, B. 1962. Die Ammonitengattung Aulacostephanus im Oberjura (Taxonomie, Stratigraphie, Biologie). Palaeontographica, Abteilung A 119, 1-172. 